\title{
Social Media As A Means For College Students Prostitution In Medan City
}

\author{
Faisal Irawan, Ibrahim Gultom, Hidayat Amsani \\ Department of Anthropology \\ State University Of Medan \\ Medan, Indonesia \\ Email: zhairahfannisairawan@gmail.com
}

\begin{abstract}
This study is a focus on the role of Social Media as a means for a college student in Medan City. The purpose of this research is to trace and know the covert prostitution network conducted by female students, using the social media as the transaction medium. According to the problem, the researcher uses Social Research type and the method used is Ethnography and describes it qualitatively, through internet browsing, social media, interview with female college students who are involved with this prostitution web, and internet prostitution network search especially in Social Media, which become research. The results show this veiled prostitution began to bloom and develop among college students in Medan city. The actors who involved in this prostitution web are mostly college students. Their ability to use and apply technological results, which in this case is the Internet and social media, has resulted in a network of prostitution that is difficult to trace and hard to see by the common people. Prostitution through the social media has been well organized and neat, complete with all the ease and practicality, by the ease of internet access itself. This prostitution has become a lucrative business field, for those with money and sex orientation.
\end{abstract}

Keywords: Social Media, Prostitution, College Student

\section{INTRODUCTION}

In this modern era, technological development and information are occurring so rapidly. Technology provides a wide range of facilities on various sides of human life. However, behind all the convenience, the required presence of human adaptation as a creator and user of technology. This is done to avoid errors in the use and take some benefits of technology. Difficulty holding the adaptation cause confusion anxiety even conflict, whether open and external nature, and hidden and internal, so that many people develop patterns of behavior deviates from the norms of general, or act arbitrarily itself regardless interruption losses that affect others. Social problems in sociology referred to as a social pathology.

According to Kartini (1981), ${ }^{1}$ Social Pathology is the science of social phenomena that are considered "pain" caused by social factors, Also called the science of "social ills." So the ills of society / social it is all human behavior is deemed inappropriate, in violation of general norms and customs, or not integrated with the general behavior. One example of this social pathology is prostitution or prostitution.

\footnotetext{
${ }^{1}$ Kartono, Kartini. 1989. Patologi Sosial, Volume I, Jakarta: CV.Rajawali
}

According to Encylopaedia Britannica $(2008)^{2}$ prostitution or prostitution, derived from the Latin, which is pro-stituere or prostauree, which means allowing oneself to commit adultery, commit fornication, adultery. An average prostitute is a prostitute or whore. Moreover, in English is called prostitution.

While Kuncoro $(2004)^{3}$ defines: "Prostitution is a form of sexual perversion, with patterns of organization impulses/sex drive that is not fair and not integrated, in the form of release of desires sex without control with many people (promiscuity), accompanied by exploitation and the commercialization of sex, without affection, impersonal nature. "

In other words, prostitution is a sales event itself with the trade in body, honor, and personality to many people to satisfy the lust of sexual desire, in return for payment. According to Wakhudin (2006), ${ }^{4}$ There are several social events of the causes of prostitution, among others:

\footnotetext{
${ }^{2}$ www.wikipedia.com/79td.ensiclopedia/2008/03/definition/prostitution/ britanica/red.8097.html

${ }^{3}$ Koentjoro. 2004 Tutur Dari Sarang Pelacur. Yogyakarta. Ink Publisher

${ }^{4}$ Wakhudin M.Pd. "Degradation Process of Moral Values in Bitch and Solutions" (Thesis). 2006 Bandung: Public Education Program. Graduate School of Education University of Indonesia
} 
1. The existence of the human urge to channel the sexual needs, particularly out of wedlock.

2. Commercialization of sex by some people to deliberately take advantage.

3. The moral collapse.

4.Semakin amount of contempt for the dignity of women and human dignity.

5. Culture exploitation of the female party.

6. The economy under the laws of demand and supply.

7. War and chaotic periods in a country.

8. Development by concentrating on the part of men.

9. The development of cities and urbanization.

10. Meets all sorts of foreign cultures with the local culture.

Regarding religion and the laws in force in the State of Indonesia, it is clear that prostitution is prohibited. Often presented the news in print and electronic media, about the various activities of the control-controlling the prostitutes who often hung in stalls or dimly lit sidewalks at night, peddling her, openly. Of course, this is disturbing the public.

However, along with the increasing sophistication of the technology in the present, then the way prostitution is also becoming more sophisticated. Commercial sex workers (CSW) is no longer peddle himself in brothels, in hotels or on the street, but it can be done through the Internet and social media. This is done because social media is considered a safe path in the transaction and not too complicated to apply it. According to Hopkins (2008)5 ${ }^{5}$, Social media is a term that not only includes various new media platforms, but also implies the inclusion of a system such as FriendFeed, Facebook, and others which are regarded as social networking. The idea is that a variety of media platforms that have a social component and as a medium of public communication. So it was. Social media is designed to facilitate telecommunications between people through the Internet.

Overview of the internet is a network or group of computers in various places around the world, connected so that inter-computer can exchange, process, and receive data (in the form

${ }^{5}$ https://pakarkomunikasi.com/pengertian-media-sosial-menurut-paraahli of digital data/encryption). This is consistent with that proposed by Gates (1999) ${ }^{6}$

"Internet(Inter-Network)is a set of computer network that connects academic sites, government, commercial, organizations, and individuals. The Internet provides access to telecommunications services and information resources to millions of users spread across the globe. The internet service includes direct communication (email, chat), discussions (Usenet News, email, mailing lists), information resources are distributed (World Wide Web, Gopher), remote login and traffic file (Telnet, FTP), and various other services.

The use of social media which is now becoming a regular thing, creating a new system of prostitution. Social media is used as a medium in sexual transactions, making it difficult detected by the legal authorities. In this case, we will clarify how social media become a major tool in business networks online prostitution among students terrain town and also how the use of social media as a promotional tool and transactions in online prostitution.

In another case, online prostitution based on social media is one of many ways to make a prostitution bisnis web and promotion, besides conventional way?

\section{METHODOLOGY}

In uncovering and entering prostitution network-based online social media, requires research that is participation. Researchers should participate in the prostitution ring, join trade and must also comply with all the rules that they have made. Therefore, social methods of ethnography is a suitable method of participation in this study ${ }^{8}$.

Researchers into the prostitution ring through your Facebook friends researcher who had previously been joined in a special online prostitution ring Medan city students. Facebook used as a promotion, even though when seen nothing different from the prostitutes facebook

\footnotetext{
${ }^{6}$ Gates, Somer. 1999.How To Build Your Own Website. USA: Drag
}

\footnotetext{
${ }^{7}$ Desmond, Achmad. 2005. Cybersex. Finally Exposed. Jakarta. Mohenjodaro

${ }^{8}$ Antonius, Bungaran. 2009. Metodologi Ilmu Sosial: Bina Media
} Pioneer 
account to another account. Facebook use was limited to the initial promotion, cause the real promotion is carried out through a private messaging service on Facebook, Instagram, and WhatsApp application.

\section{RESULT AND DISCUSSION}

In the prostitution online, social media (Facebook, Instagram, and others) and short message service (WhatsApp, BlackBerry Messenger, WeChat, Line, and others) who uses the internet is a major factor in this business. Each has a function of mutual support. Likewise in the case of the operating system, no operating groups and others individually. In this discussion will be divided into two main points of discussion are 1 . From social media use of its system and, 2 . From the system works.

1. From the system is the use of social media. The use of social media (Facebook, Instagram) is always paired with the use of internet-based short messaging service. There are two main functions of social media, namely as a means of promotion and also a means of introduction to potential customers. Social media is used because it is considered safer and more covert than with other media. In the promotion in social media was usually not very open, because of social media such as Facebook or Instagram is a social media wide open and can be accessed by anyone. Unlike the campaigns through the media short message service, such as WhatsApp, BBM, WeChat, or Line. Through these media, promotional bolder and more open because of the only people who know or who have connected who can access this service. For example: in the service status Moment WeChat WhatsApp or services, it is not unusual if we find sentences that explain that he should be hired for sexual services.

In simpler language, between Facebook, Instagram and internet-based short messaging services like BBM, WhatsApp, WeChat, can we classify into social media, because the function of the whole application is for communication and social access. However, by its nature, Facebook and Instagram tend to be more "public." While the short messaging services tend to be more "private." The use of Facebook and Instagram more focused to introduce themselves to potential customers. However, in many cases, is rarely found in pictures or posts that indicate that the account holder is a whore. Almost no difference with other accounts. This is one way that is not easy to trace. So how do I find out? Some of the ways that can be taken are to ask for recommendations from friends of his who had connected with her. Can also through private chat polite and not tacky, but must be sure that this is indeed the target of call girls. For if private chat too rough, tacky, or misplaced, it does not produce results. After successfully friends on Facebook or Instagram, then we can access a variety of images or videos that are more open and explicit than the account. Usually, it is in private albums, or he who sent through the private mail.

Having friends on Facebook or Instagram, the next step is to schedule an appointment to meet and bid price. Usually followed in a more private social media, i.e. short messaging services like BBM, WhatsApp or WeChat. Usually, there are 4 important things to be discussed include scheduling a date, the agreed price, the hotel where dating and shuttle mechanism during a date later.

However, not all prostitution networks or the promotion of prostitution always use Facebook or Instagram. Currently, it is developing through media WhatsApp, BBM and WeChat, without the use of Facebook or Instagram. This method is chosen because it is considered safer and more efficient. Moreover, by looking at the various status or moment, already known this woman call or not. For example in WeChat, using a feature look around, we can see other people around us within a radius of about two kilometers that also use WeChat. Usually female prostitutes always have a profile photo beautiful, sexy and slightly parted, and accompanied by a status overtly indicate that she was a call girl, as an example: "Need money fast ya!", "Who wants to ST (short time), chat me "," Who wants to massage plus-plus, chat me ", and various other status. However, to watch on WeChat is the number of transgender / LGBT are also open prostitution services.

While in WhatsApp, a little bit more closed, because we can not connect unless you know his phone number. This is the actual location of the security. We can connect with them if we have the cell phone number that can usually be obtained from his or her friends or former customers.

Both in WeChat or WhatsApp, they usually disguise with the words "serve massage," "spoiled service," "great story," or "hot spot." 
However, sentences or words above is indicated that they provide sexual services. However, that is not too flashy, terms such fine was used. In the services of prostitutes is also known as the term short-time and long-time or full time. Short time indicates that they are only willing to do a short date only, usually just for sex services for 2 to 6 hours. While the long-time or full-time is a service that not only sex, but also they are ready to be out of town, participate in business travel, shopping, and other activities whose duration ranging from 12 hours up to days.

2. From the system works. Can we classify into 2 types which is a network or collection, and also work on their own without involving the network. Through a network system, typically using social media like Facebook or Instagram. There are indeed have a place to practice (such as Spa, Massage, Oukup, and hotels), and some are not. However, in this network, there are usually one or two people who served as managers usually tasked to promote, organize schedules, set point and set prices for women collection. A manager is usually not just promote it online, but also offline is to enter the communities of men, club car or a motorcycle, a sports club, gym and more ${ }^{9}$. Still, its transactions conducted online.

In practice that involves a network in Spa, there are two methods of promotion done, namely through Facebook or Instagram, and also through WeChat. The difference is if on Facebook or Instagram, shown is a Spa with photographs of beautiful women who are ready to provide services to its customers spa therapy. They offer spa services for boys, with a wide selection of packages and prices, and no sentence sex services they display. Sex services will they offer at a time when consumers are in therapy, and who would serve women who provide services such therapy. The price for sexual services is also outside of the package price we have paid therapy. Any amount depending on the agreement between the consumer and the woman. Meanwhile, if through WeChat, they promote themselves individually. However, if we booked them for a date, then they will ask us to come to Spa where they operate.
While working on their own, usually more likely to use social media-based short message service. In addition to a more closed and more simple, this method is considered more flexible, because if anyone wants to go out, just with a short message. There are no standard rules applied, because it only involves two people. This method is also considered to be more profitable because the entire proceeds from the transaction obtained in full.

From the search results online prostitution using social media, the authors found that the majority of these calls are women aged between 18 years to 24 years. Same with Desmon (2005) ${ }^{10}$ data for a student in Bandung and Jakarta. This is the age of the school, college and is still considered a very productive age. However, the reality of it is, the lifestyle of students in the city of Medan that tend to consumerism, eventually brought most of them to become prostitutes to meet the needs of their hedonism. The use of social media made a gap and means for prostitution networks they build, both corporately and individually. Not wrong if we call it a phenomenon of moral degradation, especially morale among students and teenagers.

Consumer, they come from various backgrounds. From the results of interviews conducted with six female students who become prostitutes in WeChat, their customers come from the students and the general public. In fact, there are two people who had been a mistress of a businessman who frequently travels on business to the city of Medan. The difference is, when it becomes a mistress, they should not accept the offer of a date from another party. However, after not being a mistress, they both eventually returned to become prostitutes online in WeChat. While consumers who come from the student, usually a group of students of middle and upper economic levels. In this case, too they are also selective because they did not want their identity disclosed if the consumer if they are friends of their own on campus.

\footnotetext{
9 Emka, Moammar. 2008. Jakarta Underground Volume II. Jakarta. Gramedia Pustaka Utama.
}

10 Desmond, Achmad. 2005. Cybersex. Finally Exposed. Jakarta. Mohenjodaro 


\section{CONCLUSION}

From the above presentation, it can be concluded that:

1. Prostitution using social media is basically to hide prostitution, as well as a means of conducting business this forbidden, whether it is based on social media public (Facebook and Instagram), as well as the application-based short messages (WhatsApp, BBM, and WeChat)

2. In practice, prostitution through social media, there is an extensive network, and some are individual.

3. The fact that it turned out to be involved in this prostitution business is among students and teenagers, who are able and have good skills in using the technology.

\section{ACKNOWLEDGEMENT}

I would like to thanks to my lecture's, Hidayat, Ratih and Ibrahim, to all my informants who has gave me all the necessary datas to build this research and my wife who always gave me support and trust to finished this research. I hope there are some critical and suggestion for me to make this research better. Thanks so much.

\section{REFERENCES}

Kartono, Kartini. 1989. Patologi Sosial, Volume I, Jakarta: CV.Rajawali

Koentjoro. 2004 Tutur Dari Sarang Pelacur. Yogyakarta. Tinta Publisher

Desmond, Achmad. 2005. Cybersex. Finally Exposed. Jakarta. Mohenjodaro

Emka, Moammar. 2008. Jakarta Underground Volume II. Jakarta. Gramedia Pustaka Utama.

Antonius, Bungaran. 2009. Metodologi Ilmu

Sosial: Bina Media Pioneer

Gates, Somer. 1999.How To Build Your Own

Website. USA: Drag .

WA Bonger "Maatschap pelijke Oorzaken der Prostitutie" in Ehsan Faisal, M.Ag "Unraveling the Tangled Yarn Prostitution"

http://ihsanfaisal79.blogspot.com/2009/03/me ngurai-benang-kusut-prostitusi. Html
Wakhudin M.Pd. "Degradation Process of Moral Values in Bitch and Solutions" (Thesis). 2006 Bandung: Public Education Program. Graduate School of Education University of Indonesia

https://pakarkomunikasi.com/pengertianmedia-sosial-menurut-para-ahli

www.wikipedia.com/79td.ensiclopedia/2008/0 3/definition/prostitution/britanica/red.8097.ht $\mathrm{ml}$ 